\title{
Surfaces
}

\section{THE DOMESTICATION OF GENRE. NAJÎB MAHFÛZ AND THE WESTERN NOVEL}

\section{Walid Hamarneh}

Volume 1, 1991

URI : https://id.erudit.org/iderudit/1065255ar

DOI : https://doi.org/10.7202/1065255ar

Aller au sommaire du numéro

Éditeur(s)

Les Presses de l’Université de Montréal

ISSN

1188-2492 (imprimé)

1200-5320 (numérique)

Découvrir la revue

Citer cet article

Hamarneh, W. (1991). THE DOMESTICATION OF GENRE. NAJîB MAHFÛZ AND

THE WESTERN NOVEL. Surfaces, 1. https://doi.org/10.7202/1065255ar
Résumé de l'article

Un compte-rendu des manières par lesquelles Mahfûz domestique les conventions génériques du roman occidental dans le contexte égyptien. Vue d'ensemble des écrits de Mahfûz. 


\title{
THE DOMESTICATION OF GENRE
}

\section{NAJîB MAHFûZ AND THE WESTERN NOVEL}

Walid Hamarneh

\begin{abstract}
An account of the ways in which Mahfûz domesticates the generic conventions of the Western novel in the Egyptian context. Survey of the writings of Mahfûz.
\end{abstract}

\section{RÉSUMÉ}

Un compte-rendu des manières par lesquelles Mahfûz domestique les conventions génériques du roman occidental dans le contexte égyptien. Vue d'ensemble des écrits de Mahfûz.

No attempt will be made to trace the large number of themes in Mahfûz's opus to earlier western counterparts. Such an exercise in "Stoffgeschichte" will not fit my present purpose, as indicated in the title of the essay. The focus of my attention will be to examine works or themes from an abstract and general perspective, namely that of genre. Such a strategy, I think, will facilitate the attempt to understand the contribution of Mahfûz to the issue of the domestication of the western novelistic traditions within the Arabic 
context. It is an attempt to understand the "how" rather than the "why" of this process, which may be called "aesthetic transfer".

Mahfûz's reception of the western novel was mediated through a conception of genre, or more specifically, of the realistic novel of the 19th century. Yet this understanding of genre was complicit with a conception of modernity and its crisis, which manifested itself in the constant critique of the realism of the 19th century and in the ensuing attempts at readjusting the novel form. This relationship between modernity and the realistic novel should be highlighted in the context of Mahfûz, because it is within such an understanding of the western novel that its reception and domestication can be grasped. But before examining these issues in Mahfûz's writings, some words on the empirical evidence concerning his acquaintance with the western novel are necessary.

Based upon the many interviews and biographical materials available, one can point to the following characteristics of his readings from the western novel:

1-His readings were mostly in English and included works by Scott, Galsworthy, Joyce and Faulkner. He also read Balzac, Flaubert, Zola, Tolstoy, Dostoevsky, Proust and Thomas Mann in English translation. In the later period of his life he started to read French but did so with great difficulty.

2-His readings were not systematic, in the sense that he never planned to read the works or even a number of works by a specific author in a systematic manner. As his guides were usually textbooks of literary history, his readings were

/pp 5-6/

highly selective, for he would read a work by an author, followed by another work by a different one. And although he attempted to read as much as he could of the novels of some authors, there were still many important Western novels which he confessed not having read even as late as the eighties.

3-As a reader in the twentieth century, he had the luxury of being able to read works from the different phases in the development of the novel. The history of the genre did not unfold historically in front of him, as much as it was there fully developed. His earliest readings were mostly works by novelists associated with high realism, an experience that reinforces the conception of a fully developed genre. 
Following this rather long introduction, let us start examining the development of Mahfûz's work. Najîb Mahfûz was born in 1911 or 1912 . He studied philosophy and became a government employee. He started writing articles and short stories before turning to the novel. He also translated and published in 1932 James Baikie's Ancient Egypt. His first three novels were historical, and their subject matter and themes were taken from ancient Egyptian history. These were to become a part of a larger unfulfilled project of 30 novels that would have covered the whole history of Egypt. Yet following the third novel he shifted his interest to the present, and his writings of the second period which covers all the novels from al-Qâhirah alJadîdah (New Cairo) published in 1945 to the celebrated trilogy, was completed before the July Revolution of 1952, was published in 1956-7, were the writings that made him the most celebrated Arab novelist of the period. These novels have been described as realistic by all critics who wrote about them. His writings in the third period that covers Awlâd Haritnâ (translated as the Children of Gebelawi and published 1959) to Miramar (published 1967) is more complex and controversial. I will discuss these three periods in a selective manner, and will neglect the works that Mahfûz wrote and published after 1967 for reasons of space and because I think that with the exception of al-Marâyâ and Malhamat al-Harâfîsh (1977) the works of the post 1967 period are /pp 6-7/

mediocre compared to his earlier works, and have barely had any impact on the developments of the Arabic novel.

In 1970 Mahfûz stated that he made a journey that started with Scott and ended at the gates of Sarraute. This statement is to a large extent true, though it needs many qualifications. For while it is true that his work can be divided into different phases or stages, some basic and fundamental patterns and traits can be discerned in the works from all different periods. Let us start with the first one. Mahfûz was not the first Arab novelist to write historical novels, and his project of the 30 novels was not unique. A number of writers wrote historical novels some decades before him, and this genre was already very popular by the beginning of this century. Perhaps the most important, but rather neglected figure in this respect is Jurjî Zaydân. Literary critics usually treat Zaydân (1861-1914) as an important cultural figure, and add that he wrote novels that were more history than novels. They usually cite his introduction to the novel Al-Hajjâj ibn Yûsuf al-Thaqafî in which he explains how his purpose for writing historical novels is different from that of the European historical novel. He declares that he wanted to write history in the form of a story or a novel (Zaydân 1956:b). Critics have agreed with him, in almost all cases; after all he knew best what he was doing! In the case of Zaydân the novels do not necessarily reflect his own attitude, and the outcome is generally more complex than is thought. It is true that he subordinates the narrative to the historical structure. In other words, the closed basic theme in his novels, being mostly a love story in which the lovers are at first separated then reunited, is manipulated to fit into his understanding of the historical process. The interesting aspect about Zaydân's understanding of history is that it was not teleological, it was 
based on two governing principles, chronology (temporality) and causality. In the process of subordinating the narrative to this historical structure, the results vary, but are generally such that the structures of history crack the closedness of the narrative. The result is that we sometimes get a narrative that is structured in such a way as to be nearer to a "fabula", while in others it is nearer to a /pp 7-8/

"sjuzhet", although it is never pure, but always "contaminated". In Zaydân, furthermore, we get the first step towards the shift from story to plot, from mere chronology to causal structuration.

The tradition of the historical novel was taken up by other writers after Zaydân, the most prominent of whom were Muhammad Farîd Abû Hadîd and 'Alî al-Jârim ('Umar 1982:154ff., 160ff.). Though these two paid more attention to plot structuring, their historical novels were limited by their teleological understanding of the historical development in their novels. This closed structure, in addition to their rhetorically heroized style, inhibited the narrative from developing its own dynamics, so that story became subordinated to the ideas of the author. Abu Hadîd, who was the better novelist, tried to utilize the older Arabic story traditions and to rehabilitate some popular ones, but his success was rather limited from the technical literary point of view.

Mahfûz's historical novels can be considered a return to Scott, not in the sense that they were mere imitations, but as a return to a tradition of writing a novel that uses the past as its raw material but is aimed at constructing a fictional world. This fictional world is neither idealized nor romanticized but presents itself as a representation of life and reality. Although these historical novels of Mahfûz are mediocre, they are interesting because they had served as an apprenticeship through which he could develop his abilities to write and to construct a fictional world. For in writing historical novels, Mahfûz constructed fictional worlds in a way that took into consideration three aspects that are related to showing how a specific situation is chosen to function as the beginning of a series of incidents that are organized temporally and lead to a different situation at the end. These aspects can be summarized as: 1-relevance to the subject or subjects, 2-unity in relation to some issues of human interest. This unity can explain the third aspect namely, why the series of incidents that unfold within time begins where it does and ends where it does. Using the Er-form, the stories are narrated in a manner that gives the impression, or creates the illusion that it is merely a recording of events. This recording of /pp 8-9/

events impresses upon the reader another illusion, namely that no subjective judgement has shaped the story being told. This is probably one of the most fundamental "tricks" of realistic fiction. 


\section{Mahfûz and Realism}

Because the second phase of his career is usually considered the most important, more space will be allotted to it. Novels, like al-Qâhirah alJadîdah, Zuqâq al-Midaqq, Khân al-Khalîlî, Bidâyah wa-Nihâyah, and the trilogy (Bayn al-Qasrayn, Qasr al-Shawq, al-Sukkarîyah), differ in subject matter and size. The earlier ones may have functioned as studies for the crown achievement of the period, the trilogy. On examinig these works certain basic compositional regularities can be discerned. These regularities are structural, and though they are never manifest as one single pattern, they form the basis for, or the logic of the different patterns in the different works.

Realistic novels include a whole repertoire of details. These details were traditionally considered not essential to the movement of the story, but mere ornaments. Realistic novels are based on what has been called the motivation of action which involves "accounting for" in terms of natural causality. These two characteristics pull in opposite directions, but throughout the development of realism, motivation started to gain the upper hand. Motivation, that is, involved by then the weaving of those details, formerly considered unessential to the story, into the chain of causality.

Realistic fiction, thus, was characterized by a change from what Tomachevsky called artistic or compositional motivation (based on traditional conventions) to realistic motivation (based on what happened earlier or on account of chance). The story then became (to paraphrase W. Martin) pushed by its past. Randomness and causality, accident and inevitable destiny had to be balanced or silhouetted in realistic fiction in the wards of Marshall Brown.

Any one acquainted with merely the plots of most of Mahfuz's novels of this period will immediately discern that this

/pp 9-10/

kind of motivation is the motor of the narrative. Chance, for instance, provides the trigger for the movement in the story. In al-Qâhirah al-Jadîdah, the stroke of Mahjûb's father complicates his financial situation. He chooses a path of action that is caused by the incident, but which is in conformity with his character. This leads to his downfall, but the downfall is not merely a result of blind fate. It is also caused by his actions. Mahjûb thinks that he can bend fate. The irony of fate, which he thinks he is bending, makes him 
become its victim. He is in the words of his friend 'Alî Tâhâ "at once the beast and the prey". He is a product of his own way of thinking and behaviour, namely that you can beat them at their own game by playing it. Such an irony is that of high realism.

Another constructional regularity in Mahfûz is his continuous, systematic, and even stubborn use of a specific set of materials that are associated with what Barthes called "the real". This material "requires no justification because it seems to derive directly from the structure of the world" (Culler 1975:140). Such material can be either what humans take for granted about themselves, such as having bodies and minds, being able to think, imagine, dream, remember, feel pain and joy, become sick, and lastly die; it may be one of those natural phenomena like day, night, seasons, clouds, rain, storms, or wind, or it may consist of references to particular entities that are considered to be generally known like names of cities, countries, or important historical figures and incidents. All these are usually conceived to function as a part of what has been termed the setting of the story. But they do also have another function which is related to what David Lodge was referring to when he defined realism as "the representation of experience in a manner which approximates closely to description of similar experience in non-literary texts of the same culture" (Lodge 1977:25). This implies that realism does not necessarily imitate "reality", as much as it adopts the standards and strategies of those non-literary discourses that describe experience in words, claim to be, and are socially acknowledged as being, "true representations" of the actual world. Realistic texts, therefore, closely approximate other texts that have acquired the legitimacy of representation in

/pp 10-11/

order to claim their own legitimacy. All forms of realism utilize these elements in order to provide credence and authenticity, thereby naturalizing discursive conventions.

A less privileged status than the materials associated with the real is assumed by cultural specific stereotypes and accepted knowledge. Mahfûz uses these materials abundantly, and can be described as the master of not only using Egyptian cultural codes, but also more specifically the urban Cairene ones of which he exhibits a profound knowledge. Following the classification of such materials by Martin into two classes (1986:67-68), I will discuss in more detail their appearance in the opus of Mahfûz, as they play such an important role in the crystallization of the realistic tradition in the Arabic novel. They are:

1. Practices that make up our social world. These are called by Barthes action sequences (1968) and by Schank and Abelson (1977) scripts or plans. 
These practices are mixtures of sequences of causally related and socially conventional behaviour like customs, rituals, modes of socially sanctioned patterns. They include in Mahfûz's fiction prayer, going to the cafe, behaviour patterns and cliches in ceremonies like marriages, funerals...etc. These practices constitute a massive store of information about reality that Mahfûz used either by describing them in detail (such as in the first 200 pages of Bayn al-Qasrayn with the breakfast scene being the most prominent example), or by mentioning one or two elements only, and thereby invoking the whole sequence without going into the details. Such practice occurs in the latter parts of the same novel or more extensively in the shorter novels (especially Zuqâq al-Midaq and Khân al-Khalîlî). But Mahfûz used these practices in three different ways. One is the kind of script or plan that Schank and Abelson call instrumental, where actions are prescribed, i.e., where the conventional series is followed to the letter. The second is what Schank and Abelson call a "situational script" namely one that involves choices and contingencies related to the situation, in the sense that social conventions allow for more than one course or series of actions. In Khân alKhalîlî for instance, Ahmad keeps

/pp 11-12/

facing the choice between reading or going to the cafe, an activity that was conventional for people of his age and status. The third has been termed "personal scripts" or plans that arise from shared knowledge of goals and ways of achieving them but that allow the individual in question a much wider range of choices and alternative courses of action. Here more complex still follow patterns that can be easily discerned as they are related to the character of the person. They are, in a sense, predictable if one knows the character well enough, since they are based on choices between alternatives that are available to the person in question. In other words, they are like the traditional Christian interpretation of God's omniscience of the future despite the insistence on man's freedom. In al-Qâhirah al-Jadîdah Mahjûb's choices, as an opportunist, are based upon what we get to know about the corruption of society from his perspective, which determines his ways of achieving his goals. But there are many junctures at which possible alternatives offer themselves and in which he writes the scripts and signs them with his own signature.

2. The storehouse of cultural stereotypes, proverbial expressions, ethical maxims etc. that are based upon cultural generalizations. These are so abundant in Mahfûz's novels that one need not cite any in particular, as each description of a cafe or a street (as in Zuqâq al-Midaq) or of certain characters (Mu'allim Nûr in Khân al-Khalîlî or Mu'allim Nûnû in Zuqâq alMidaq) can be quoted as an instance of this. Mahfûz does yet another thing when invoking these elements, as they are sometimes refuted through daily practice, thereby achieving one of the forms of realistic irony. 
Another regularity in Mahfûz's realistic fiction is what was termed in critical theory as the naturalization achieved through the conventions of the literary genre (Culler 1975:145ff). In his case one aspect gains prominence, namely access to the consciousness of characters as one of the primary conventions on which his narratives are founded. A lot can be said about this, but I will single out one point here. Mahfûz digested the novel as a realistic genre at its stage of full development. He recognized that no single point of view (in / pp 12-13/

the ordinary sense of the term and not in the old technical sense of who narrates) is adequate for the representation of reality. So his omniscient narrator allows us to see events from different points of view (without resorting to the multiple-form of narration as he later did in such novels as Mîramâr which will be discussed in a later chapter) by recognizing that each character claims to be uniquely in possession of truth, therefore, many points of view, especially those of the main characters, are depicted in their variety (their voices are felt or perceived rather than directly heard). This accounts for the centrality of free indirect discourse and free indirect speech, which was one of the two important innovations of Mahfûz in matters related to novelistic language. The second of these is the perfection and regularization of the use of transformations of the colloquial or dialect into modern standard Arabic. And although Mahfûz was not the first to use either of the two, he was the one who perfected their usage and "canonized" them within the emerging language of the novel.

To return to the issue of allowing characters to depict their own point of view, one can discern here the underlying assumption of the high realistic attitude (read modern), complicit with traditional liberalism, that reality can be known only through consensus, which is the expression and mediation of different perspectives as they are revealed through the passage of time. This explains what has been described as the objectivity of Mahfûz, i.e., his ability to depict despicable characters with as much sympathy as lovable or adorable ones. Yet as much as liberalism is essentially bounded by the political, and would halt its consensus ideology when it comes to interrogate its basic principles and to erode them, or when this same ideology is applied to other spheres such as the economic, so does the consensus end when it reaches the voice of the author/narrator, who functions like a benevolent despot. This author/narrator does not become democratic (we shall discuss this point in more detail later).

Another regularity is the centrality of space/place. Action and incidents usually occur in specific and well described spaces with /pp 13-14/

clear boundaries. Most of the action in Zuqâq al-Midaq takes place in the alley and its houses, shops, and cafe. Forty of the seventy one chapters of 
Bayn al-Qasrayn take place in the family house and twelve in the father's shop. In the second part of the trilogy, Qasr al-Shawq, thirteen chapters take place in the father's house, three in his shop, and eight in al-Abbasîyah palace. In the third part, al-Sukkarîyah, twelve chapters take place in the father's house and twelve in the house in al-Sukkarîyah. In the second and third parts of the trilogy, we get a wider variation of places with the new characters who are introduced. But these places are always bound and confined. They are restricted spaces. This restriction of space helps provide a frame for the movement of the characters, but it also limits the manouverability of the narrative, which is compensated for by resorting to complex temporal organization and techniques on the one hand, and memory and recollection on the other.

Space in the novels of Mahfûz restricts the movement but provides condensation. This is exactly what is needed in a fictional world that is not idealistic, romantic, or heroic. It is that of the ordinary man, and is, therefore, ordinary. But because it is constructed as ordinary, it assumes the power of the "natural place" or "habitat" of the characters, so that whenever one leaves the place one belongs to, a disequilibrium occurs, and the character starts to fall (Hamîdah in Zuqâq al-Midaq is the best example of this). So place has also another function which is symbolic, and a study of this aspect would necessitate a study of the whole geography of Mahfûz's Cairo.

Place in the novels of Mahfûz is always described, but rarely in elaborate detail. One can notice the strategy of one of the oldest tricks of realism, in which the description of one section or part of the place that can be immediately by the reader to complete the picture, as the places in which action happens are usually ordinary, at least from the perspective of the average reader. But whenever the place to be described is unusual, the emphasis is always on the peculiar, odd, or different.

/pp 14-15/

If we turn to the issue of time, we find that the temporal organization is carefully structured and reinforced by constant references to historical data or facts, most of which are commonly known. In the trilogy, ages of characters, seasons, months, times, etc. are meticulously calculated as has been noted by some critics. But due to the restrictions of space discussed earlier, we discern a complex usage of external, internal, and mixed analepses, to use Genette's terms. Very little prolepsis, which is common to realism in general, is resorted to. 
With respect to narrative time one finds generally a lot of ellipses, some descriptive pauses, and very little summary. Scene (in Genette's sense) is encountered mostly in dialogue.

Endings, on the other hand, tend to be mostly open. Characters in Mahfûz's novels, like the rest of us, usually act in accordance with the shared set of assumptions about unity, causality, origin, and end. And whenever generations are found, as in the trilogy, succession serves as an earthly counterpart for the mythical or religious conception of time.

All these regularities betray a specific conception of the subject. And as we showed earlier, Mahfûz was not the first Arab novelist to introduce the modern concept of the individual subject, but in his novels of this period, it is the elaboration or working out of what I termed earlier as the subject/ individuum that is central. The constitution of the fictional subject/ individuum is a discursive strategy that is based upon the regularities mentioned above. This s/i is taken to be a complex entity constituted by the interaction of a multiplicity of forces and tensions such as heredity, social environment (family, class, culture, geography) and personal experience in relationship to the social world, i.e., the interaction of the personal with the public. The construction of a character is, within such a paradigm, a process of fitting all these elements in such a way as to provide an explanation or motivation for the kind of actions and reactions the character does and shows. If this is done meticulously and carefully, the character (the s/i) becomes credible and convincing.

/pp 15-16/

\section{Mahfûz and Experimentation}

I will turn now to the third period, and quickly throw out some ideas without elaborating on them as much as was done in my discussion of the second period. Many critics have claimed that a complete turn took place in the writing of Mahfûz and necessitates a distinction be made between the former realistic period and the one that has been called symbolic or philosophical. I think that although some new and important changes took place, yet the fundamental principles upon which the strategies of fictional construction remained the same. Most of the regularities mentioned above apply to this period, although some need partial revisions. 
Space remained central for the works of this period (the pension in Mîrâmâr and the house-boat in Thartharah fawq al-Nîl). The utilization of "natural", cultural, and stereotypical materials is still abundant. Temporal organization is still very meticulous, calculated, and accurate, but the usage of analepsis and memory is resorted to much more than in his earlier works. This is usually done through resorting to the interior monologue, which was used in the novels of the second period, but less systematically. The Er-form of narration is perforated with interior monologues that take the place of free indirect discourse (as in al-Liss wa-al-Kilâb and al-Summân wa-al-Kharîf). The Ich-form of narration becomes central in some of the works where the multiple Ich-form narration is used (this will be discussed later with respect to Mîrâmâr).

The most important differences between the novels of this period and those of the second are the relative decrease in authorial intervention and the relative democratization of the modes of narration. The question of representation of reality gains more complexity and becomes more problematic, but the possibility of representation is never questioned. The basic tenets of realism are still valid, because what is questioned in this period is reality itself, not its representability.

/pp 16-17/

As can be seen from this quick and condensed survey, the novels of Mahfûz show a structure that is basically that of the realistic novel in the period of high realism. And as the reception of the European novel in Mahfûz's works was mediated by a conception of genre, this conception was utilized creatively in the construction of the specific Mahfüzian fictional worlds. In this sense, Mahfûz was the real "importer" of the western novel as a genre because, although he was not the first to import it, he was the first to domesticate it. Domestication is usually more problematic and difficult than creation.

I propose to call this Mahfûzian project "domestication through socialization". The term socialization would then refer to a three-level process, that includes first, the normative that is derived from the literary conventional; second, the normative that is derived from the culturally specific; third, the normative that is derived from the fundamental grounding principles of the construction of the natural. 
Other Arab writers before Mahfûz were able to utilize one or another level of this process, but it was with him that the three levels were brought together, making him the first modern Arab novelist.

Such an interpretation of Mahfûz's reception of the European novel probably facilitates the attempt to understand not only his achievements, but also his limitations, because such conceptions of genre upon which his novels are founded, proved to be an obstacle to the further development of the Arabic novel. And although he attempted to transcend some of the limitations of his method (as we shall see later). These limitations and to his towering achievement, presented a real obstacle that had to be surmounted by the younger generation of writers who were growing under his shadow.

\section{A Note On Mîrâmâr And Relativized Narration}

When Mahfûz published Mîrâmâr in 1967, it was to be the last work of his experimental realistic period that followed the period /pp 17-18/

of high realism. Mahfûz remained committed to his "realistic" attitude of the possibility of representation, although he started questioning the degree of the complexity of reality, and the respective degree of complexity needed to represent this reality. It was within such parameters that his experimentation with form during this period took shape, and Miramâr is both historically and artistically, the culmination of this period.

The form of narration here too is the multiple Ich-form. Four narrator/ characters follow one another in telling the story, something that not only reminds of Faulkner's The sound and the Fury and Durrell's Alexandria Quartet, but also of Fathî Ghânim's al-Rajul al-ladhî faqada zillahu. Each of the four narrators is allotted an almost equal space. 'Amir Wajdî begins and ends narration (pages 5-59 and 175-186), to be followed by Husnî 'Allâm (59-92), Mansûr Bâhî (92-135), and Sirhân al-Buhayrî (136-175). Despite the clear relative privileging of 'Amir as a narrator who begins and ends the narrative, and with whom the authorial sympathies lie, he in no way dominates the narrative, nor its narration. He does not become the mouthpiece of any voice beyond the text, but remains, as a narrator/ character consequent with his fictional existence. An old man with a rich past whose nostalgia to his revolutionary past and estrangement from the present, do not make him forget the present and the future. His language is always flavoured with words and usages that betray his political and social background as a veteran Wafdist (abundance of pre-1952 political jargon and Koranic verses). 
Husnî starts his narrative with the words that immediately show the kind of person he is, "Firîkîkû". His sense of the meaninglessness of things, his failures, his indifference, his sarcasm, his cynicism, are all given in capsule form in some of his formulations. The same applies to the other two narrators. Mahfûz excels in utilizing a method which he had already mastered in his earlier works, namely to transform the spoken dialectal forms into a standard grammatical Arabic without loosing the liveliness and the flavour of the spoken tongue, something that is almost completely

/pp 18-19/

absent in the case of al-Safinah. The jurisdiction of each narrator is also accurately set, not only in relation to one's character, age, ideology, and position within the story, but also to each incident that takes place. The argument between Zahrah and Sirhân is narrated by 'Amir, then by Husnî, who adds a further dimension, and last by Sirhân himself who provides the most reliable version of the incident.

Despite all this one cannot claim that the narrators in Mîrâmâr are liberated from a force that stands above them. What we have here is relativised rather than democratic narration. We get different perspectives and voices. But these are still regulated by a force that maintains the balances and checks between the different narrators in order to provide a comprehensive picture of a reality that is representable. It is the impossibility of representing reality from one perspective and through one voice that necessitates this divisional perspectivization. The multiple narrators cumulate in order to present a more comprehensive picture of reality. This in a way reinforces the authority of narration and the narrator(s) much more than it undermines them by showing or even foregrounding their relativity. Yet it is one step further from that authoritarian traditional narrator, or even the Ich-form narrators who speak with the authority of the Er-form narrator and are mere vehicles for the voice of the author.

University of Toronto, Centre for Comparative Literature

Toronto - ONT M5S 1A1 - Canada

/pp 19-20/ 
Surface Page d'Acceuil/Home Page

\section{WORKS CITED}

'Alim, Mahmûd Amin

1970.Ta'ammulât fî 'âlam Najîb Mahfûz. al-Qâhirah: al-Hay'ah al-Misrîyah al-'Ammah lil-Kitâb.

'Ayyâd, Shukrî Muhammad

1968.al-Qissah al-Qasîrah fi Misr. al-Qâhirah: Jâmi'at al-Duwal al-'Arabîyah.

'Id, Rajâ'

1974.Dirâsah fî adab Najîb Mahfûz: tahlîl wa-naqd. al-Iskandarîyah:

Munsha'at al-Ma'ârif.

'Id, Yumnâ see: Hikmat Sabbâgh al-Khatîb

Badr, 'Abd al-Muhsin

1963.Tatawwur al-riwâyah al-'Arabîyah al-hadîthah fî Misr. al-Qâhirah: Dâr al-Ma'ârif.

1978.Najîb Mahfûz. al-Qâhirah: Dâr al-Thaqâfah.

Bakhtin, M.M.

1981.The Dialogic Imagination: Four Essays.Austin: University of Texas Press.

Barthes, Roland

1965.Le Degré zéro de l'écriture. Paris: Gonthier.

1984.Le bruissement de la langue. Paris: Seuil.

Culler, Jonathan

1975.Structuralist Poetics. Ithaca: Cornell UP.

Dîb, Yâqût et.al. (eds)

1989.al-Rajul wa-al-qimmah. al-Qâhirah: al-Hay'ah al-Misrîyah al-'Ammah lilKitâb.

/pp 20-21/

Draz, Céza Kassem 
1985.Binâ' al-riwâyah: dirâsah muqâranah li-thulâthîyat Najîb Mahfûz.

Bayrût: Dâr al-Tanwîr.

Faraj, Nabîl

1986.Najîb Mahfûz: hayuhu wa-adabuh. al-Qâhirah: al-Hay'ah al-Misrîyah al-'Ammah lil-Kitâb.

Ghânim, Fathî

1962.al-Rajul al-ladhî faqada zillahu. [Cairo]: Ruz al-Yûsuf. (English translation The Man Who Lost His Shadow, tr. Desmond Stewart. London: Chapman \& Hall, 1966.

Hasan, Muhammad 'Abd al-Ghanî

1970.Jurjî Zaydân.al-Hay'ah al-Misrîyah al-'Ammah lil-Kitâb.

Hasan, Muhammad Rushdî

1974.'Athar al-Maqâmah fî Nash'at al-Qissah al-Misrîyah al-Hadîthah. alQâhirah: al-Hay'ah al-Misrîyah al-'Ammah lil-Kitâb.

Khatîb, Hikmat Sabbâgh

1986.al-Râwî al-mawqi' wa-al-shakl. Bayrût: Mu'assasat al-Abhâth al-'Arabîyah.

Kratschkovsky, Ignaz

1930/31. "Der historische Roman in der neueren arabischen Literatur" Die Welt des Islams II:51-87.

Lodge, David

1977.The Modes of Modern Writing. Ithaca: Cornell UP.

Mahfûz, Najîb

1967. Mîrâmâr. Bayrût: al-Maktabah al-'Ilmîyah al-Jadîdah.

(English translation Miramar, tr. by Fatma Moussa-Mahmoud. Washington: Three Continents Press, 1983).

/pp 21-22/

Martin, Wallace

1986.Recent Theories of Narrative. Ithaca: Cornell UP

Muhammad Sa'îd, Fâtimah al-Zahrâ'

1981.al-Ramzîyah fî adab Najîb Mahfûz. Bayrût: al-Mu'assasah al-'Arabîyah lil-Dirâsât wa-al-Nashr. 
Muwaylihî, Muhammad

1964.Hadîth 'Isâ ibn Hishâm aw Fatrah min al-Zamân. al-Qâhirah: al-Dâr alQawmîyah.

Najjâr, Walîd

1985. Qadâyâ al-sard 'inda Najîb Mahfûz. Bayrût: Dâr al-Kitâb al-Lubnânî.

Najm, Wadi'ah Tâhâ

1968.al-Jâhiz wa al-Hâdirah al-'Abbasîyah. Baghdâd:Matba'at al-Irshâd.

Naqqâsh, Rajâ'

1970.Aswât ghâdibah fî al-Adab wa-al-Naqd. Bayrût: Dâr al-Adâb.

Peled, Matityahu

1983.Religion, My Own: The Literary Work of Najib Mahfuz. New

Brunswick, N. J.: Transaction Books.

Qâsim, Sîzâ (see Ceza Kassem Draz)

Rabî'î, Mahmûd

1985.Qirâ'at al-riwâyah: Namâdhij min Najîb Mahfûz. al-Qâhirah: Maktabat al-Zahrâ'.

Râghib, Nabîl

1967.Qadîyat al-shakl al-fannî fî adab Najîb Mahfûz. al-Qâhirah: al-

Mu'assasah al-Misrîyah al-'Ammah lil-ta'lîf wa-al-Nashr.

/pp 22-23/

Schank, Roger, and Robert Abelson

1977.Scripts, Plans, Goals, and Understanding: An Inquiry into Human

Knowledge Structures. Hillsdale, N.J.: Erlbaum.

Sharqâwî, 'Abd al-Rahmân

1958.al-Ard. al-Qâhirah: Dâr al-Kitâb al-'Arabî.

Shukrî, Ghâlî

1969.al-Muntamî. Misr: Dâr al-Ma'ârif.

Somekh, Sasson

1973.The Changing Rythm: A Study of Najîb Mahfûz's novels. Leiden: Brill.

Tarâbîshî, Jûrj 
1973.Allâh fî rihlat Najîb Mahfûz al-Ramzîyah. Bayrût: Dâr al-Talî'ah. Tuwâtî, Mustafâ

1986. Dirâsah fî riwâyât Najîb Mahfûz al-dhihnîyah. Tûnis: al-Dâr alTûnisîyah.

Zaydân, Jurjî

1956.al-Hajjâj ibn Yûsuf.al-Qâhirah: Dâr al-Hilâl.

$/ \mathrm{p} 23 /$ 